\title{
Chronic Kidney Disease, Stage 3
}

National Cancer Institute

\section{Source}

National Cancer Institute. Chronic Kidney Disease, Stage 3. NCI Thesaurus. Code C80389.

Long-standing and persistent renal disease with glomerular filtration rate (GFR) between 30-59 $\mathrm{ml} / \mathrm{min}$. 